\title{
CULTIVATION OF HUMAN RESOURCES FOR EFFECTIVE INTERNATIONAL EXPANSION BY AN EMERGING-MARKET MULTINATIONAL: IMPLICATIONS FOR GLOBAL MARKETING
}

\author{
Tanses GÜLSOY \\ Beykent University, Turkey
}

\section{ABSTRACT}

There is ample research on the process through which multinationals from developed countries manage their human resource strategies globally. However, little research has been conducted on the international human resource strategies of multinationals from emerging markets. This study is an attempt at redressing this research gap by examining the global human resource strategies of an emerging-country multinational specifically with reference to how the compay's internationationalization and global marketing efforts impact its global human resource management strategies and the influence in turn of the company's HRM strategies on its international expansion and global marketing efforts. The article draws on data collected through face-to-face interviews with key managers of Turkey's leading white goods manufacturer Arçelik.

Keywords: Emerging-market multinationals, international expansion, international human resource strategy, global marketing

\section{INTRODUCTION}

Effective international expansion by emerging-market multinationals is an area that has drawn considerable interest over the last few years (e.g., Ramamurti and Singh, 2009; Brennan, 2010; Yaprak and Karademir, 2011). Among the main antecedents of international expansion of emergingmarket multinationals are research and development and design capabilities, production process capabilities, access to home country resources, use of networks and relationships, and expertise (UNCTAD, 2006). While the capability building that appears to be a necessary precursor to effective international expansion has been studied in terms of technological capability building, total quality management, and distribution network building (e.g., Duysters et al., 2009; Bonaglia et al., 2008), not as much attention has been paid to the cultivation of human resources as it relates to the emergingmarket firm's internationalization strategies (Khavul et al., 2010). This study is an attempt at exploring the ways in which an emerging-market multinational builds its human resources as part of its international expansion and global marketing strategies. Specifically, we are concerned with what sort of actions an emerging-market multinational needs to take in terms of its human resource policies and practices to support its global marketing efforts and whether these policies differ between developed and developing market contexts.

The remainder of the paper is organized as follows: First, we provide a review of the theoretical background and literature on the relationship between human resource management and global marketing. Next we describe our methodology. We then offer an overview of Arçelik's human resource practices as they relate to the company's internationalization and global marketing efforts based on face-to-face interviews with some key company executives and an examination of archival 
data. Finally, we discuss the implications of the results, with limitations of the study and possible future directions for research.

\section{LITERATURE REVIEW AND RESEARCH FRAMEWORK}

Superior human resource management can be a sustained source of competitive advantage in the global economy, as suggested by Hill (2008: 510). There is a rich body of international human resource management literature by developed-country firms (see for example Dessler, 2011, and Wood, 2006). Also, issues dealing with how multinationals manage their far-flung human resources has long been reported (for example, Rosenzweig and Nohria, 1994, as cited in Chang et al., 2009). On the other hand, research on international human resource management practices of firms from emerging markets is scarce (Chang et al., 2009).

A firm's capability in managing its human resources is key for enhancing innovation (e.g., Yiu et al., 2007), which along with technological capability is recognized to be an important factor in international expansion (e.g., Porter, 1990/1998; Cho et al., 1998; Som, 2006; Luo and Tung, 2007; Liu and Buck, 2009; Sun, 2009). An expanding body of research suggests that internationalization patterns of emerging-market multinationals differ in some significant ways from those of their more established counterparts from developed countries (see for example, Ramamurti and Singh, 2009, and Brennan, 2011). It is possible that the human resource strategies adopted by these emerging-market companies also differ from those employed by developed-market multinationals.

The extent and pattern of human resource management by multinational companies in a particular country is likely to depend upon a number of factors such as the multinational's philosophy and general strategy towards its foreign operations; the nature of its long-term resource commitments and the length of its involvement in that country; the kind of activities in which the company is engaged; the availability and quality of lcoal support and training facilities; its market (or expected market) share; and the role played by governments in fostering educational advancement and the upgrading of workplace competence (Dunning and Lundan, 2008: 444). Headquarters' product innovation capability, enterprise scale, its international experience, local market conditions, and dependence of subsidiaries on local institutions have also been suggested as exerting varying degrees of influence on the company's human resource strategies (Liu et al., 1998). Another factor that may impact the company's human resource strategies may be the maturity of the subsidiary operation (Wocke et al., 2007).

Dunning and Lundan (2008: 418) suggest that globally integrated multinational enterprises draw their managerial, professional, and technical workforce from a worldwide employment pool. For emergingmarket multinationals the availability of a worldwide pool of managerial, professional, and technical talent may be limited. Especially in developed markets these companies may face a number of challenges such as liability of foreignness and latecomer disadvantages which may hamper their ability to attract and retain qualified human resources. They may also face image problems associated with poor product quality. As these companies tend to have fewer resources and less international experience, they may also find it more difficult to spread management know-how across subsidiaries. Furthermore, the evolution to a global orientation may require organizations to develop the ability to put together top management teams and a multicultural strategic orientation (Sambharya, 1996, as cited in Harvey et al., 2000). It is possible that in their effort to overcome the challenges facing them in foreign markets, emerging-market multinationals may employ specific human resource strategies. The HR policies and practices employed by these companies especially in personnel planning, 
recruitment, and selection may have implications for global marketing as they may be partly determined by the competitive situation confronting the company's brands in its foreign markets. The differentiation bases chosen for global competitiveness are also likely to impact the company's HR strategies, as suggested for example by Porter (1985).

The developing markets may present other problems such as risk and lack of infrastructure (e.g., Cavusgil et al., 2002). It is possible, however, that in developing markets emerging-economy multinationals may stand at an advantage rather than a disadvantage vis-a-vis their counterparts from developed economies because they may be better able to adapt to and navigate the local conditions (Cuervo-Cazurra and Genc, 2008) and - as is the case in the former Soviet Union countries for example - they may have entered these markets at about the same time as their developed-economy counterparts and therefore may not face latecomer disadvantages or the formidable challenge of competing against well-established global brands (Gülsoy, Özkanlı and Lynch, 2013). Another way in which the developing-market context may differ for emerging-market multinationals is the fact that they may have entered developing markets just as other multinationals were withdrawing from them (Cooke, 2012).

By extension of the above argument, the ways in which multinationals from emerging markets manage their human resources in developed and developing markets may be different from those of their more established counterparts from developed countries. The human-resource policies of emerging-market multinationals may contrast sharply between developed and developing market contexts, as indicated, for example, by Zhu et al. (2011) and Chang et al. (2009).

Furthermore, the rapid internationalization of emerging-market multinationals may present them with additional challenges regarding international human resource management.

This study explores the following research questions:

1. What are the specific human-resource strategies employed by multinational companies from emerging markets?

2. Do the human-resource strategies adopted by multinational companies from emerging markets differ between developed and developing market contexts?

3. How do emerging-market multinationals deal with the challenges of rapid internationalization as it relates to international human resource management?

4. What are the implications of the international human-resource strategies of emerging-market multinationals for global marketing?

This study aims to explore the research questions above through an examination of Arçelik's human resource policies and strategies. Arçelik has been chosen for this study because it has embraced international expansion as a strategy for longer than a decade. Furthermore, various examinations have pointed to the company as an example of a successful emerging-market multinational (see, for example, Bonaglia et al., 2007; Bonaglia et al., 2008; Ghemawat, 2008).

\section{METHOD}

A case study approach was utilized, using 25 face-to-face interviews by the author to gather data on management practices. Triangulation was achieved by additional sources of data, including company documents, published research reports, and the business press in addition to Turkish government official statistics. 
Our respondents included twenty-one senior Arçelik executives, four of whom were assistant general managers. Research suggests that the reliability of key informant responses is greater for informants in higher hierarchical positions vs. lower hierarchical positions (Homburg et al., 2012). Also included among our respondents were a former country manager (Beko UK) and one manager from the foreign trade arm of the Koç Group (Ram). Among the company executives that we interviewed we tried to select - as much as circumstances permitted - long-serving company executives with the aim of throwing light on some of the strategy choices of the past with the evidence from the closest witnesses. Furthermore, we tried to obtain also the perspective of outside observers to develop an understanding of the trends in the industry; therefore, our respondents included also two industry body representatives.

For reasons of confidentiality, we do not identify the individual managers and the senior industry representatives that we interviewed beyond their titles. Two respondents - both of whom were Arçelik executives - were interviewed twice. Though not all of the above-mentioned sources have been referred to in the following discussion, they were largely responsible for informing it.

Prior to the interviews, we identified the relevant senior executives and made appointments to see them. The interviews each lasted one-and-a-half to two hours. Twenty-two interviews were taperecorded, and three interviews were documented by written notes. For the tape-recorded interviews we hold the full evidence and have used this in the research material. The respondents are designated by title.

\section{RESEARCH EVIDENCE}

\section{The company}

Arçelik is the leading manufacturer in Turkey's white goods market with over a 50\% market share with its three brands Arçelik, Beko and Altus (Arçelik Annual Report 2011, p. 7) and Europe's third in terms of unit sales (Arçelik Annual Report 2011, p. 8). Its total revenues in 2011 were 5.05 billion US dollars (Koç Holding Annual Report 2011, p. 49). Turkey's sixth largest industrial organization (Istanbul Chamber of Industry, 2012), the company is considered the flagship company of Turkey's biggest conglomerate Koç, which is one of the Fortune Global 500 (Fortune, 2011, July 25). Arçelik is owned $40.5 \%$ by Koç Holding, $16.7 \%$ by other Koç Group companies; $17.6 \%$ by the Burla Group while $25.2 \%$ of shares are publicly traded (Koç Holding Annual Report 2011, p. 49).

\section{A global orientation}

Arçelik's internationalization efforts can be dated back to the late 1960s, when sporadic exports began, and the company may be said to have made international expansion an integral part of its strategy since 2001. (For a discussion of the company's internationalization effort, its antecedents and consequences, please see Gülsoy, Özkanlı and Lynch, 2013). Arçelik’s international sales made up 53\% of consolidated sales for 2011 (Arçelik Annual Report 2011, p. 10). Its Beko brand is a leader or comes second or third in various home appliance product segments in the UK, Poland, France, Romania, and Lithuania (Arçelik Annual Report 2011, p. 22), just to give an indication of the brand's standing in various European markets. Besides the three brands mentioned above, the company has Blomberg and Grundig, Arctic, Flavel and Leisure, Elektrabregenz, and the most recent acquisition of Defy - a total of ten brands. Apart from its eight production plants in Turkey, the company has six production plants in four countries: a production plant each in Romania, Russia, and China, and three in South Africa. Its sales and marketing organization spanning 20 countries extends from the UK to 
Australia (Arçelik Annual Report 2011, p. 21). Arçelik's annual reports since the 2009 version bear the title: "Respects the globe. Respected globally," clearly indicating the company's global orientation. Again, the company's annual report bears a section titled: "Target Market: The Globe" (Arçelik Annual Report 2011, pp. 20-31). These are only a few of the indications of a firm positioning itself as a global company.

Arçelik employs nearly 22,000 people (Arçelik Annual Report 2011, p. 61), with one-third of the entire workforce, or more than 7,300 people, working outside of Turkey (ibid.). An important indication of the company's international expansion plans is the creation of a position of assistant general manager of marketing in 2010 (interview note).

A large body of academic research suggests that a company's human resource practices should fit with the company's strategy for the company to be highly profitable (Hill, 2008). At the beginning of the millennium, along with other departments at Arçelik, the human resource department also reexamined its processes so as to be able to support the company's international expansion strategy. This vision, unveiled in 2008 , led to a "global human resource management quest," noted the company's human resources director (interviewed in September of 2011).

In a meeting of a professional association of Turkey's human resource management professionals at Arçelik's Sütlüce, Istanbul headquarters on April 7, 2011, an HR specialist from Arçelik explained a four-pronged human resource strategy that the company adopted in transforming itself into a "global company". These were attracting the requisite talent, managing the talent within the company in the right way, rotation, and continuous development. The specialist explained that in the past five years more than 100 employees had been appointed to other countries.

The human resource director explained that the challenge facing the HR department was "cultivating people ... who know international trade, international law, international economics... people who are truly open to different cultures, who can live anywhere around the world, who can do business with citizens of any country around the world, and people proficient in foreign languages. This is what we focused our development programs on."

"We are successful internationally, but from now on we will be a global company. First, we will continue to grow internationally. We will especially focus on branded growth. We will invest in certain developing regions. So, we will increase our presence abroad. ... [T]wo, as we do this, we have to develop our organization and our human resources so as to be able to foster global talent." (Human resource director)

We next look at the role the company's human resource policies and practices play in its internationalization and global marketing efforts.

\section{Human resources at Arçelik: A key strength in international expansion}

Research suggests that one of the precursors to internationalization is building firm-specific assets (e.g., Dunning and Lundan, 2008) though the FSAs leveraged by emerging-market firms may be different from those of their more established counterparts in developed markets (e.g., CuervoCazurra and Genc, 2008). Human resources appears to have been a critical asset in the internationalization of Arçelik. Several Arçelik managers interviewed mentioned its people as one of the reasons for the company's successful international expansion.

"[The company] has employed Turkey's best-trained engineering teams. ... Human resources from the best universities," (Assistant General Manager). 
Another manager also pointed out that the engineering talent the company had at a time when welltrained human resources were not so easily available constituted a competitive strength for the company (Marketing Director, Turkey).

The human resource director of Arçelik mentioned the company's human resources as its greatest strength. Attracting some of Turkey's best graduates for many years, the company has also made "serious" investments in human resources, she pointed out. This strength was apparently instrumental in the company's internationalization effort. When the company started establishing overseas plants in the early 2000s, it relied on its engineering staff. "In those days many people went overseas as expatriates."

A strategic asset Arçelik appears to have also relied on in its international expansion efforts is the Koç Group. The business group was instrumental in opening doors to and familiarizing the company with foreign markets (e.g., Bonaglia et al., 2008; Gülsoy et al., 2013). In 1999 a series of mergers of Koç Group companies under Arçelik was responsible for increases in sales and profits (Arçelik Annual Report 1999, p. 7). The gradual integration of Beko Elektronik with Arçelik helped unify the research and development activities of the two leading electronics companies within the group (Bonaglia et al., 2008). The ability of diversified business groups to mobilize their human resources for new ventures quickly rather than having to seek them on the market has been noted (Amsden, 2009: 75). In establishing its overseas network Arçelik also seems to have drawn upon the management skills within the group (Bonaglia et al., 2008; Gülsoy et al., 2013). Therefore, it stands to reason that a discussion of Arçelik's human resource policies and practices geared towards internationalization should begin with a discussion of some of the benefits yielded by group membership. In terms of human resource management, a successful practice of talent retention within the group bears special attention.

The Koç Group has around 81,000 employees (Koç Holding Annual Report 2011, p. 5). This human resource base apparently provides a significant advantage for the companies within the group, and Arçelik also seems to benefit from it. Several key managers have come from other group companies, such as the General Manager and several of the assistant general managers (Arçelik Annual Report 2011, pp. 92-93). Some of the high-level executives interviewed furnish further examples, including the company's human resource director. This indicates that the Koç Group values the experience gained within it and points to a policy that favors management continuity. This policy appears to lead to increased organizational commitment. Arçelik's Human Resource Director explained: "Turnover occurs at more junior levels. ... [In higher-level positions] there is a very strong sense of belongingness." The average length of service of the Arçelik employees in Turkey is 7.6 years, and their average age is 33.2 years (Arçelik Annual Report 2011, p. 61).

Management continuity may also be one of the determinants of the technological capability building at Arçelik. There is some evidence that managerial tenure impacts organizational innovation positively because the longevity of managers in their jobs provides legitimacy and knowledge of how to accomplish tasks, manage political processes, and obtain desired outcomes within the corporate structure (Kimberly and Evanisko, 1981). The same sort of commitment-oriented human resource policies seem to have been adopted in the research and development function. As Arçelik embraced the goal of internationalizing with its branded products, it made significant investments in research and development (see for example Bonaglia et al., 2008). One of the human-resource policies adopted in laying the groundwork for the company's research and development efforts was allowing the researchers time for acquiring the requisite know-how and developing themselves for five years before the research and development center would be required to show any results (Gülsoy et al., 2011). A policy aimed at retaining engineering talent in engineering jobs was the establishment of two 
career tracks - one for management and one for specialists - where those choosing the specialist track are assured of comparable salary levels to those on the management track so as to prevent defection to the management track for financial reasons (ibid.).

International expansion, while drawing on the company's strength in human resources, has also had a definite impact on the company's human resource policies and strategies. "Since 2001 we focused on cultivating global people," noted the Human Resource Director.

Here are some of the human resource policies and practices aimed specifically at supporting the company's global organization and international expansion efforts:

\section{Recruitment and staffing}

Companies may use several types of staffing to fill the jobs in its foreign subsidiaries. Staffing policies may use an ethnocentric approach, where all key management positions are filled by parentcountry nationals; a polycentric approach, which requires host-country nationals to be recruited to manage subsidiaries; or a geocentric approach, where the organization looks to fill key jobs with the best people throughout the organization, regardless of nationality (Hill, 2008: 512-514). Some research suggests that emerging-market multinationals tend to adopt a polycentric approach to management in developed- country subsidiaries while in other emerging markets they adopt predominantly an ethnocentric approach (e.g., Thite et al., 2012).

The interview evidence indicates that Arçelik favors a polycentric approach in general. "Our priority is to work with local teams. They understand the dynamics of that country better," noted the Human Resource Director. Expatriates may be used for critical positions or know-how transfer. For example, in order to transfer production technologies, expatriate staff is used for a certain time period in overseas production plants.

Here the human resource director pointed out the importance of another element besides the development level of the market.

"The maturity level of the company is very important. In Russia we have a company that we established. You buy the land and build a factory on that land. At the beginning, there was a serious size of Turkish expatriate cadres going there... In more established organizations you may keep fewer expatriates."

Local managers constitute around 80 to $90 \%$ of management. For example, in the UK, at the time of the interview with the Human Resource Director in 2011, only the country manager and the manager for financial affairs were from Turkey. Again, the decision to opt for host-country managers vs expatriates appears to depend on the maturity level of the company. In mature sales organizations the number of Turkish expatriates does not exceed 5, informed the Human Resource Director. "We send some of our people to develop them as product managers."

In production companies, by contrast, management is predominantly Turkish if there is a need for cadres to be developed from below. "In Russia, $80 \%$ of management is Turkish. Except for sales," explained the human resource director. In Romania, on the other hand, there were only four Turkish expatriates at the time of the interview, with even the country manager not a parent-country national. In management positions also the company seems to be veering towards locals. In fact, where necessary, the company seems to adopt also a geocentric policy: "We don't look at expatriate staffing as just from Turkey. There can be an expat going from the UK to Russia," (Human Resource Director). 
While expatriates are an important means of transferring core competencies and maintaining a unified corporate culture, their success is predicated on a number of determinants, such as flexibility, cultural openness, and the ability of the expatriate's family to adapt to the host country (Winfred and Bennett, 1995, as cited in Dessler, 2011: 665). Arçelik administers a number of tests to potential overseas assignees to measure flexibility and adaptability. There is also training offered to expatriates to prepare them for their overseas assignments. The company also tries to ease the adaptation of the overseas assignee's family to the host country as well. "We on our end try to make them as comfortable as possible in that country," (Human Resource Director).

One of the ways in which a strategy of international expansion appears to impact HR strategy is by influencing selection criteria. Some of the qualifications sought in new recruits are flexibility, differentiability, and creativity.

\section{Training and development}

Development of international sales executives appears to have been traditionally on-the-job. The company has high-level international sales managers with considerable experience of a wide variety of foreign markets, in both developed and developing countries, as required by a policy of rotation (as mentioned both by a Manager of International Sales at Arçelik and a Sales\&Marketing Business Unit Manager at Ram). Especially before the establishment of the company's overseas sales offices, experience gained at the trading arm of the Koç Group (Ram) appears to have been critical in the company's effective internationalization. In fact, some of Arçelik's key managers today appear to have gained their international experience at the training ground provided by Ram. Today, serving at one of the company's subsidiaries overseas appears to be an important step towards senior management positions in the corporate hierarchy.

The company's annual report states that Arçelik carries out leadership capability assessments and provides its employees with the opportunity to participate in international development programs "in order to take role in the global organization of the company as effective leaders" (Arçelik Annual Report 2011, p. 87). The company is a corporate partner of CEMS, which is an alliance of business schools and multinational companies and runs a master's program in international management (CEMS, 2012). Another member is Koç University, a non-profit foundation university established by the foundation bearing the name of its founder Mr. Vehbi Koç, also the founder of the eponymous business group (Koç University, 2012).

Though a comprehensive examination of all of the training programs available at Arçelik or the Koç Group is beyond the scope of this study, here is a look at some of the internationalization-oriented programs. The "overseas leadership program" is offered to the managers working in the subsidiaries of the company to improve their management skills (Arçelik Annual Report 2011, p. 87). An "international management development program" is aimed at supporting the development of employees with the potential for overseas assignments (Arçelik Annual Report 2011, p. 87). As part of this program, those prepared for overseas assignments receive training in the "Global Manager" and "Global Executive" programs, designed and implemented in conjunction with Koç University (Arçelik Annual Report 2011, p. 87). Also, various seminars are given to help familiarize employees with the cultures of those countries that are potential markets for the company (Arçelik Annual Report 2011, p. 87). 


\section{DISCUSSION AND CONCLUSION}

Our study of a Turkish multinational offers some interesting insights into the way multinational companies from emerging markets manage their human resources so as to increase a global orientation, and it starts with HRM policies targeting first the home office. Interview accounts and published company reports all emphasize the key role played by an ample reservoir of trained personnel both within Arçelik and the Koç Group. Careful selection, strong training and development, a powerful corporate culture that reinforces organizational commitment, a tendency to recruit internally, and an organizational structure that encourages innovation appear to be important in accumulating the necessary human resource base that would enable the firm to become globally competitive.

The transition to a multinational company requires effective development of international human resource management policies and practices. Arçelik appears to use home-country nationals selectively: to transfer core competencies and to prepare managers for top-level positions within the corporate hierarchy. The key determinant of whether a predominantly ethnocentric or polycentric staffing approach will be used appears to be the maturity level of the operation in the foreign country. Where the operation is considered to be mature, a polycentric approach seems to be favored. The careful screening that overseas assignees go through and the training they receive prior to assuming their assignments also point to the company's commitment to internationalization.

Today Arçelik's workforce hails from twenty countries extending from Europe to China to Australia. Managing these far-flung subsidiaries and committing them to the company's strategic goals appears to be a daunting task. How the company will fare may prove useful for emerging-market multinationals from other countries. They may yield some insights also for developed-country multinationals.

A strong corporate culture appears to be important in increasing organizational commitment and cultivating desired employee behaviors. In transferring this culture across Arçelik's subsidiaries may require the efforts of expatriate managers and the training of local cadres in the company's key values.

Arçelik's human resource policies and practices suggest that for the strategy of international expansion to be effective it has to be supported by the requisite human resource strategies. The investments made in human resources over the years - and specifically, the investment in developing the research-and-development and international sales and marketing capability in the 1990s - appear to have been instrumental in the company's internationalization effort. As such, they have clear implications for global marketing: Where technology development and innovation are chosen to be the basis for competitiveness, the company needs to make the necessary investments in attracting, selecting, and developing its human resources towards that end. International expansion also necessitates continued investment in human resource development; the type of training offered at Arçelik reflects the company's global orientation.

The importance of marketing is recognized in the creation in 2010 of the position of an assistant general manager of marketing. Again, these human resource policies indicate a growing awareness of the criticalness of marketing in the company's international expansion efforts. There appears to be a strong tradition of overseas salesmanship at Arçelik, with some managers having served for years in a wide variety of markets. In-house accumulation of such experience appears to be an invaluable asset for the company's current and future global marketing efforts.

As companies without the support of powerful business groups behind them may be hard-pressed to make such investments in human resources, there are also some implications here for public policy in 
terms of establishing the necessary infrastructure such as incentive provision to smaller enterprises for $\mathrm{R} \& \mathrm{D}$, technology incubators, or encouragement of university-business collaborations.

The study of a leading multinational company from Turkey may yield insights regarding the impact of human resource management strategies on internationalization and global marketing by other emerging-market companies.

Although case studies yield a richness of data that may not be gained from quantitative studies, they do have some limitations. The case study of a leading Turkish company may not be representative of Turkish multinational companies across sectors in terms of their human resource or global marketing strategies. A possible venue of exploration could therefore be examining multinationals in different industries. Another limitation is that this study has largely focused on corporate HR policies and practices. Further studies could explore, for example, the degree of standardization of human resource practices across the subsidiaries of emerging-market multinationals with a more detailed examination at the local subsidiary level of such HR functions as recruitment, selection, training and development, performance appraisal, and compensation policies as well as their impact on internal marketing and global marketing efforts. Internal marketing and its impact on global marketing in emerging-country multinationals is an area of scarce study and may prove fruitful to pursue. Multiple case studies of multinationals from Turkey could help highlight the differences among the human resource strategies of various firms with different firm-specific assets and facing different challenges.

\section{Acknowledgement}

The data for this study was gathered as part of a joint project involving in addition to the author also Professor Richard Lynch (Emeritus Professor of Strategic Management, Middlesex University, London, UK) and Professor Özlem Özkanlı (Head of Management and Organization Chair, Faculty of Political Sciences, Ankara University, Ankara, Turkey). The author would like to thank both colleagues for their insightful guidance and collaboration in the larger project since June of 2008 . Special thanks are due also to Arçelik executives, former and current Koç Group executives, and the two industry experts for their kind participation. 


\section{REFERENCES}

Amsden, A. H. (2009). "Does firm ownership matter? POEs vs. FOEs in the developing world." In R. Ramamurti and J.V.Singh (Eds.), Emerging Multinationals in Emerging Markets (pp. 64-77). Cambridge, UK: Cambridge University Press.

Arçelik Annual Report 1999. [Arçelik Faaliyet Raporu 1999.] Istanbul: Arçelik A.Ş., 2000.

Arçelik Annual Report 2011. Istanbul: Arçelik A.Ş., 2012. Retrieved in September 2012, from http://www.arcelikas.com.

Bonaglia, F.; Colpan, A. M.; and Goldstein, A. (2008). "Industrial upgrading in the white goods global value chain: The case of Arçelik." Institute for Technology, Enterprise and Competitiveness, Working Paper Series 08-04.

Bonaglia, F.; Goldstein, A.; and Mathews, John A. (2007). “Accelerated internationalization by emerging markets' multinationals: The case of the white goods sector." Journal of World Business, No. 42.

Brennan, L. (2011). The Emergence of Southern Multinationals: Their Impact on Europe, Palgrave Macmillan, Basingstoke.

Cavusgil, S.T.; Ghauri, P.N.; and Agarwal, M.R. (2002). Doing Business in Emerging Markets: Entry and Negotiation Strategies. Thousand Oaks, CA: Sage Publications Inc.

CEMS. (2012). "The Global Alliance in Management Education." Retrieved September 26, 2012, from http://www.cems.org.

Chang, Y.Y.; Mellahi, K.; and Wilkinson, A. (2009). "Control of subsidiaries of MNCs from emerging economies in developed countries: the case of Taiwanese MNCs in the UK." The International Journal of Human Resource Management, 20 (1): 75-95.

Cho, D.S.; Kim, D.J.; and Rhee, D.K. (1998). Latecomer strategies: Evidence from the semiconductor industry in Japan and Korea. Organization Science, 9 (4): 489-505.

Cooke, F.L. (2012). "The globalization of Chinese telecom corporations: Strategy, challenges, and HR implications for the MNCs and host countries." The International Journal of Human Resource Management, 23 (9): 1832-1852.

Cuervo-Cazurra, A. \& Genc, M. (2008). "Transforming disadvantages into advantages: Developingcountry MNEs in the least developed countries.” Journal of International Business Studies, Vol. 39, pp. 957-979.

Dessler, G. (2011). Human Resource Management, $12^{\text {th }}$ edition. Upper Saddle River, NJ: Pearson.

Dunning, J.H. and Lundan, S. M. (2008) Multinational Enterprises and the Global Economy, $2^{\text {nd }}$ Edition. Cheltenham, UK: Edward Elgar.

Duysters, G.; Jacob, J.; Lemmens, C. and Jintian, Y. (2009). "Internationalization and technological catching up of emerging multinationals: A comparative case study of China's Haier group." Industrial and Corporate Change, Vol. 18, No. 2, pp. 325-349.

Fortune. (2011, July 25). Retrieved December 14, 2012, from http://money.cnn.com/magazines/fortune/global500/2011/full_list/index.html.

Ghemawat, P. (2008). “Arçelik Home Appliances: International Expansion Strategy.” Harvard Business School, No. 9-705-477.

Gülsoy, T.; Özkanlı, Ö.; and Lynch, R. (2011). "The Role of Innovation in the Effective International Expansion of an Emerging-Country Firm: The Case of Arçelik,", International Conference on Leadership, Technology, and Innovation Management, Istanbul, Turkey, December 2-4, 2011, Procedia Social and Behavioral Sciences, Volume 41, 2012: 116-129.

Gülsoy, T.; Özkanl1, Ö.; and Lynch, R. (2013), "Effective International Expansion Strategies of Emerging Countries: The Strategies that Helped Arçelik," Management Research Review, 36 (1): 432. 
Harvey, M.G.; Novicevic, M.M.; Speier, C. (2000). “An innovative global management staffing system: A competency-based perspective.” Human Resource Management, 39 (4): 381-394.

Hill, C.W.L. (2008). Global Business Today. New York, NY: McGraw-Hill Irwin.

Homburg, C.; Klarmann, M.; Reimann, M.; and Schilke, O. (2012). "What drives key informant accuracy?" Journal of Marketing Research, 49 (August): 594-608.

Istanbul Chamber of Industry [Istanbul Sanayi Odas1]. (2012). “Turkey’s Top 500 Industrial Enterprises 2011.” Retrieved September 29, 2012, from http://www.iso.org.tr.

Khavul, S.; Benson, G. and Datta, D.K. (2010). "Is internationalization associated with investments in HRM? A study of entrepreneurial firms in emerging markets." Human Resource Management, 49 (4): 693-713.

Kimberly, J.R. and Evanisko, M.J. (1981). “Organizational innovation: The influence of individual, organizational, and contextual factors on hospital adoption of technological and administrative innovations." Academy of Management Journal, 24 (4): 689-713.

Koç Holding Annual Report 2011. Istanbul: Koç Holding A.Ş., 2012. Retrieved in September 2012 from http://www.koc.com.tr.

Koç University. (2012). Retrieved October 15, 2012, from http://www.ku.edu.tr.

Liu, X. and Buck, T. (2009). The internationalisation strategies of Chinese firms: Lenovo and BOE. Journal of Chinese Economic and Business Studies, 7 (2): 167-81.

Liu, S.-J.; Huang, T.-L.; and Chen Q.-H. (1998). “International development of Taiwan's information industry: An empirical study on human resource strategy of overseas subsidiaries." IEEE Transactions on Engineering Management, 45 (3): 296-310.

Luo, Y. and Tung, R. (2007). International expansion of emerging market enterprises: A springboard perspective. Journal of International Business Studies, 38: 481-498.

Porter, M.E. (1985). Competitive Advantage: Creating and Sustaining Superior Performance. New York, NY: The Free Press.

Porter, M.E. (1990/1998). The Competitive Advantage of Nations. New York, NY: Palgrave.

Ramamurti, R. and Singh, J. V. (Eds.). (2009). Emerging Multinationals in Emerging Markets. Cambridge, UK: Cambridge University Press.

Som, A. (2006). "Bracing for MNC competition through innovative HRM practices: The way ahead for Indian firms." Thunderbird International Business Review, 48 (2): 207-237.

Sun, S. L. (2009). "Internationalization strategy of MNEs from emerging economies: The case of Huawei." Multinational Business Review, 17 (2): 129-155.

Thite, M.; Wilkinson, A.; and Shah, D. (2012). "Internationalization and HRM strategies across subsidiaries in multinational corporations from emerging economies - A conceptual framework." Journal of World Business, 47: 251-258.

UNCTAD (United Nations Conference on Trade and Development). (2006). World Investment Report 2006. FDI from Developing and Transition Economies: Implications for Development. United Nations Conference on Trade and Development.

Wocke, A.; Bendixen, M.; and Rijamampianina, R. (2007). "Building flexibility into multinational human resource strategy: A study of four South African multinational enterprises." International Journal of Human Resource Management, 18 (May): 829-844.

Wood, G. (2006). International human resource management. In Tom Redman and Adrian Wilkinson (Eds.), Contemporary Human Resource Management: Text and Cases, $2^{\text {nd }}$ edition, (pp. 263-277). Upper Essex, UK: Pearson Education Limited.

Yaprak, A. and Karademir, B. (2011). “Emerging market multinationals' role in facilitating developed market multinationals' regional expansion: A critical review of the literature and Turkish MNC examples." Journal of World Business, 46 (4): 438-446. 
Journal of Global Strategic Management | V. 6 | N. 2 | 2012-December | isma.info | 23-35 | DOI: 10.20460/JGSM.2012615771

Yiu, D.W.; Lau, C.-M.; \& Bruton, G.D. (2007). International venturing by emerging economy firms: The effects of firm capabilities, home country networks, and corporate entrepreneurship. Journal of International Business Studies, Vol. 38 (4), pp. 519-540.

Zhu, Y.; Lynch, R.; and Jin, Z. (2011). "Playing the game of catching-up: Global strategy building in a Chinese company." Asia Pacific Business Review, 17 (4): 511-533. 